\title{
IMPLEMENTASI CYBER NOTARY DI INDONESIA DITINJAU DALAM UPAYA REFORMASI BIROKRASI ERA 4.0
}

\author{
Fadhila Rizqi \\ Universitas Pembangunan Nasional Veteran Jakarta \\ Jl. RS. Fatmawati, Pondok Labu, Jakarta Selatan 12450 \\ Email: fadhilarizqi10@gmail.com \\ Siti Nurul Intan Sari D. \\ Universitas Pembangunan Nasional Veteran Jakarta \\ Jl. RS. Fatmawati, Pondok Labu, Jakarta Selatan 12450 \\ Email: sinuinsada@yahoo.com
}

\begin{abstract}
Abstrak
Implementasi pelayanan publik berbasis teknologi dalam bidang kenotariatan belum dilaksanakan semaksimal mungkin di Indonesia. Penjelasan Atas Pasal 15 ayat (3) Undang-Undang Nomor 2 Tahun 2014 tentang Perubahan Atas Undang-Undang Nomor 30 Tahun 2004 tentang Jabatan Notaris menegaskan bahwa cyber notary berlaku hanya dalam kewenangan sertifikasi kegiatan transaksi antara Notaris dan Penghadap, namun tidak dalam kewenangan kenotariatan dalam lingkup yang lebih luas. Untuk mendorong pelayanan publik berbasis teknologi di bidang kenotariatan yang efektif dan efisien, maka perlu dikaitkan dengan Reformasi Birokrasi di Indonesia, terlebih melihat perkembangan teknologi yang sangat pesat di era 4.0 saat ini. Rumusan masalah dalam penelitian ini adalah bagaimana keuntungan dan keterkaitan penerapan cyber notary di Indonesia dalam upaya reformasi birokrasi era 4.0 saat ini? dan bagaimana eksistensi dan peraturan perundang-undangan cyber notary di negara civil law, khususnya Negara Belgia dan Perancis?. Penelitian hukum ini ialah penelitian hukum normatif yang menggunakan data sekunder dengan pendekatan undang-undang dan pendekatan komparasi yang selanjutnya dianalisis secara kualitatif. Birokrasi cyber notary perlu diimplementasikan di Indonesia, sebab dapat membantu penyelenggaraan pemerintah yang mencapai good governance. Untuk memperoleh landasan hukum yang kuat terkait cyber notary, maka Indonesia harus mengubah Undang-Undang Jabatan Notaris, Pasal 1868 KUHPerdata, dan Pasal 5 ayat (4) huruf b Undang-Undang Informasi dan Transaksi Elektronik.
\end{abstract}

Kata Kunci: cyber notary, reformasi birokrasi, studi komparasi, civil law 
IMPLEMENTASI CYBER NOTARY DI INDONESIA DITINJAU DALAM UPAYA REFORMASI BIROKRASI ERA 4.0 (STUDI KOMPARASI DENGAN NEGARA CIVIL LAW) (Fadhila Rizqi, Siti Nurul Intan Sari D.)

Abstract
The implementation of technology-based public services in the notary sector has not been carried out as fully as possible in Indonesia. Elucidation of Article 15 paragraph (3) of Law Number 2 of 2014 concerning Amendments to Law Number 30 of 2004 concerning Notary Position affirms that cyber notary applies only in the authority of certification of transaction activities between Notaries and Persons, but not within the authority of notary in a wider scope. To encourage technologybased public services in the field of the notary that are effective and efficient, it is necessary to link them to Bureaucratic Reform in Indonesia, especially considering the very rapid development of technology in the current 4.0 era. The formulation of the problem in this research is how the advantages and relationships of the application of cyber notary in Indonesia in the current era 4.0 bureaucratic reform efforts and how the existence and laws of the cyber notary in civil law countries, especially Belgium and France. This legal research is normative legal research that uses secondary data with a statutory approach and a comparative approach which is then analyzed qualitatively. Cyber notary bureaucracy needs to be implemented in Indonesia, because it can help government administration to achieve good governance. To obtain a strong legal basis related to the cyber notary, Indonesia must amend the Law on Notary Position, Article 1868 of the Civil Code, and Article 5 paragraph (4) letter $b$ of the Information and Electronic Transactions Law.

Keywords: cyber notary, bureaucratic reform, comparative study, civil law

\section{PENDAHULUAN}

Survei United Nations melalui e-Government Development Index (EGDI) tahun 2020 menunjukkan bahwa tingkat implementasi Sistem Pemerintahan Berbasis Elektronik atau yang disingkat SPBE di Indonesia berada pada peringkat ke-88 dari total 193 negara dengan peringkat Lower Middle Income atau Pendapatan Menengah ke Bawah. ${ }^{1}$ Peringkat tersebut merupakan indikator apakah digitalisasi berupa layanan publik, perkembangan infrastruktur, dan kecakapan sumber daya manusia di Indonesia telah dieksekusi semaksimal mungkin atau masih dalam tahap perkembangan. $^{2}$ Berkaca pada negara tetangga seperti Malaysia yang

${ }^{1}$ United Nations (Department of Economic and Social Affairs), E-Government Survey 2020, (New York: United Nations, 2020), hlm. 261.

2 Igif G. Prihanto, "Studi Komparasi Pengembangan e-Government Negara-Negara Anggota Perserikatan Bangsa Bangsa untuk Mendukung Pengembangan 
berhasil menempati urutan ke-47 dengan predikat Upper Middle Income atau Pendapatan Menengah Atas $^{3}$, dan Negara Singapura menempati peringkat ke-11 dengan predikat High Income atau Pendapatan Tinggi dari total 193 negara. ${ }^{4}$

Dalam kaitannya dengan Revolusi Industri 4.0, sebagai sumber daya manusia yang berintelektual, secara langsung dituntut untuk menciptakan suatu inovasi baru terutama di bidang pelayanan publik dan mengimplementasikannya dengan berbasis Teknologi, Informasi, dan Komunikasi (TIK) $)^{5}$ guna mengefisiensi dan mengefektifkan jalannya pelayanan publik seiring dengan perkembangan masyarakat. Menurut Hidayaningrat terkait definisi pelayanan publik yang dikutip dari Suwondo tahun 2001, menjabarkan bahwa pelayanan publik sebagai suatu layanan jasa dilaksanakan guna memberikan kemudahan bagi masyarakat dengan mengutamakan syarat-syarat efisiensi, efektivitas, serta penghematan. ${ }^{6}$ Dalam hal melakukan pembaharuan serta perubahan mendasar kaitannya dengan pelayanan publik guna mengefektifkan berbagai hal, erat kaitannya untuk menciptakan inovasi baru ke arah yang lebih maju dari yang sebelumnya, yakni Reformasi Birokrasi.

Reformasi Birokrasi adalah suatu proses perubahan yang bersifat mendasar menuju situasi dan kondisi yang dikehendaki guna merespon kondisi birokrasi saat ini serta tuntutan ke arah perbaikan. ${ }^{7}$ Website resmi Kementerian Pendayagunaan Aparatur Negara dan Reformasi Birokrasi menyinggung bahwa dengan adanya perubahan lingkungan yang strategis serta pesatnya kemajuan ilmu pengetahuan dan TIK menuntut birokrasi

e-Government di Indonesia", Jurnal IPTEK-KOM, Vol. 15 No. 2, Desember 2013, hlm. 157.

${ }^{3}$ United Nations (Department of Economic and Social Affairs), Op. Cit., hlm. 262.

${ }^{4}$ United Nations (Department of Economic and Social Affairs), Op. Cit., hlm. 264.

${ }^{5}$ Irfan Setiawan, "Pengembangan Teknologi Informasi dan Komunikasi Dalam Menghadapi Era Revolusi Industri 4.0 Di Kota Pontianak", Jurnal Teknologi dan Komunikasi Pemerintahan, Vol. 1 No. 1, Oktober 2019, hlm. 3.

${ }^{6}$ Rizky Hersya Pratama, Abdul Hakim, Muhammad Shobaruddin, "Pelayanan Publik Berbasis Teknologi Informasi dan Komunikasi (TIK), Elektronik Rukun Tetangga/Rukun Warga (e-RT/RW) (Studi e-Government di Kelurahan Ketintang Kecamatan Gayungan Pemerintah Kota Surabaya)", Jurnal Administrasi Publik (JAP), Vol. 3 No. 12 , hlm. 2129.

7 Yusriadi, Misnawati, "Reformasi Birokrasi Dalam Pelayanan Publik (Studi Pelayanan Terpadu Satu Pintu)”, Jurnal Ilmiah Ilmu Administrasi Publik, Vol. 7 No. 2, Juli - Desember 2017, hlm. 100. 
IMPLEMENTASI CYBER NOTARY DI INDONESIA DITINJAU DALAM UPAYA REFORMASI BIROKRASI ERA 4.o (STUDI KOMPARASI DENGAN NEGARA CIVIL LAW) (Fadhila Rizqi, Siti Nurul Intan Sari D.)

pemerintahan agar segera direformasi guna menyesuaikan tuntutan dinamika masyarakat. ${ }^{8}$

Pelayanan publik dalam praktiknya terdapat dua jenis pelayanan, diantaranya pelayanan pemerintah dan non-pemerintah. Namun dalam jenis pelayanan non-pemerintah sangat erat kaitanya dengan penyelenggaraan layanan publik dan peraturan perundang-undangan, sebab wewenang dan fungsinya diatur jelas dalam undang-undang, seperti halnya layanan notaris. ${ }^{9}$ Notaris merupakan pihak pejabat umum atau orang yang diberi wewenang oleh undang-undang untuk membuat akta otentik. ${ }^{10}$ Peraturan perundang-undangan terkait tugas dan wewenang seorang Notaris diatur dalam Undang-Undang Nomor 30 Tahun 2004 tentang Jabatan Notaris (UUJN) yang mewajibkan dilakukannya pembuatan akta otentik guna menciptakan perlindungan dan kepastian hukum. ${ }^{11}$

Dalam praktiknya, layanan notaris di Indonesia masih bersifat konvensional, yang artinya aktivitas antara notaris dan penghadap masih dilakukan secara tatap muka. Pada Era Revolusi Industri 4.0 saat ini, sebagai generasi yang kerap kali menghadapi transformasi digital, maka wajib untuk melek teknologi terhadap perkembangan-perkembangan yang ada di masyarakat. Hal ini dapat pula diterapkan dalam kehidupan hukum berupa layanan notaris berbasis teknologi infromasi atau yang dikenal dengan cyber notary ${ }^{12}$. Gagasan cyber notary memiliki konsep yakni dengan memanfaatkan kemajuan teknologi informasi bagi notaris untuk menjalankan tugas kenotariatannnya, diantarannya dalam mendigitalisasi dokumen, menandatangani akta otentik secara elektronik, memanfaatkan telekonferensi dalam pelaksanaan Rapat Umum Pemegang Saham perusahaan (RUPS). ${ }^{13}$

8 Kementerian Pendayagunaan Aparatur Negara dan Reformasi Birokrasi, "Reformasi Birokrasi", https://www.menpan.go.id/site/reformasi-birokrasi/makna-dantujuan (diakses 26 Oktober 2020).

${ }^{9}$ Kadek Setiadewi dan I Made Hendra Wijaya, "Legalitas Akta Notaris Berbasis Cyber Notary Sebagai Akta Otentik", Jurnal Komunikasi Hukum (JKH) Universitas Pendidikan Ganesha, Vol. 6 No 1, Februari 2020, hlm. 127.

${ }^{10}$ Lumbuan Tobing, Peraturan Jabatan Notaris, (Jakarta: Erlangga, 1983), hlm 30.

11 Herianto Sinaga, "Tanggung Jawab Werda Notaris Terhadap Akta yang Dibuatnya", Jurnal Premise Law, Vol. 6, 2015, hlm. 1.

12 Edmon Makarim, Notaris dan Transaksi Elektronik; Kajian Hukum tentag Cyber Notary atau Electronic Notary, (Jakarta: PT Raja Grafindo Perkasa, 2013), hlm. 117.

${ }^{13}$ Respati Nadia Putri, "Konsep Cyber Notary Dalam Perubahan Undang-Undang Jabatan Notaris Sebagai Hasil Program Legislasi Nasional", Tesis Magister, Fakultas Hukum Universitas Padjadjaran Bandung, 2017, hlm. 13 
Dalam Undang-Undang Nomor 2 Tahun 2014 tentang Perubahan Atas Undang-Undang Nomor 30 Tahun 2004 tentang Jabatan Notaris (PUUJN) telah diatur mengenai Cyber Notary dalam Pasal 15 ayat (3) yang menyatakan bahwa berlakunya cyber notary hanya dalam kewenangan sertifikasi kegiatan transaksi antara Notaris dan Penghadap, namun hal tersebut belum diimplementasikan dalam kewenangan notaris secara menyeluruh seperti pembuatan akta. Hal inilah yang menjadi titik perhatian bahwa cyber notary di Indonesia belum dilibatkan penuh dalam kehidupan hukum terkhusus layanan notaris, karena belum adanya regulasi yang jelas mengatur cyber notary secara menyeluruh.

Esensi peraturan perundang-undangan tentang Notaris di Indonesia perlu dilihat serta dikomparasi dengan peraturan perundang-undangan di negara civil law lainnya, sebab negara lain telah melangkah jauh lebih maju dibanding Indonesia dalam pelaksanaan transaksi Notaris yang telah berbasis teknologi, diantaranya Negara Belgia dan Negara Perancis yang telah merubah KUHPerdatanya untuk melegalkan pembuatan akta otentik berbasis elektronik. Namun sayangnya Indonesia belum mengikuti perkembangan terhadap revolusi di bidang kenotariatan berbasis elektronik, dan juga pihak pemerintah tidak mengindahkan hal ini. Maka dari itu, perlu adanya atensi khusus dari berbagai pihak terlibat guna mengetahui pentingnya diterapkannya layanan notaris berbasis elektronik.

Untuk itu, penting dilakukannya penelitian ini karena dalam implementasi cyber notary di Indonesia masih banyak menuai pro dan kontra dari masyarakat, dan penelitian ini akan membahas sepenuhnya terkait keuntungan dan keterkaitan penerapan cyber notary di Indonesia dalam upaya Reformasi Birokrasi Era 4.0, serta eksistensi dan peraturan perundang-undangan cyber notary di negara civil law, khususnya Negara Belgia dan Perancis.

\section{METODE PENELITIAN}

Metode pada penelitian ini yaitu metode Yuridis Normatif, yang merupakan penelitian hukum doktriner atau penelitian kepustakaan dengan mengkaji studi dokumen dan telaah terhadap literatur serta menggunakan data sekunder yang terdiri dari bahan hukum primer, sekunder dan tersier. Penelitian hukum ini menggunakan pendekatan statute-approach dan comparative-approach yang selanjutnya dianalisis secara kualitatif. Teknik pengumpulan data yang digunakan ialah deskriptif analisis dengan menguraikan dan menganalisis masalah secara rinci berdasarkan teori hukum terkait. 


\section{PEMBAHASAN}

\section{Keuntungan dan Keterkaitan Penerapan Cyber Notary di Indonesia dalam Upaya Reformasi Birokrasi Era 4.0}

Kemajuan teknologi memberikan peluang yang sangat luas bagi masyarakat dalam kepentingan banyak hal. Beralihnya era teknologi informasi 4.0 ini melahirkan suatu inovasi baru dalam sektor pelayanan publik. Digitalisasi pelayanan publik merupakan suatu faktor mendasar kaitannya dengan kemudahan layanan guna menciptakan pelayanan berbasis teknologi yang mengutamakan syarat-syarat efisiensi, efektivitas, serta penghematan. ${ }^{14}$

Pelayanan publik dalam bidang kenotariatan masih dilakukan secara konvensional dan belum melibatkan teknologi informasi secara keseluruhan. Maka dari itu peran teknologi informasi dalam bidang pelayanan publik dapat pula diterapkan di kehidupan hukum berupa layanan notaris berbasis teknologi informasi atau yang kerap dikenal dengan konsep cyber notary. Berbagai keuntungan dalam pengimplementasian cyber notary di Indonesia telah menjawab berbagai tuaian pro dan kontra dari masyarakat.

Urgensi kewenangan kenotariatan secara elektronik dikemukakan dalam International Congress XXIV dari Latin Notaris pada tahun 2004 dan dibahas di kelompok kerja tema kedua (working group theme II) yang pada inti dari pembahasannya yaitu membuka diri dengan mengakomodir perkembangan dan menyadari suatu kemungkinan terjadinya pembuatan akta otentik secara elektronik. ${ }^{15}$ Hal ini secara tidak langsung menuntut notaris untuk segera dan siap menghadapi transformasi digital, sebab keterlibatan teknologi informasi mempengaruhi kemudahan dalam berbagai kebutuhan masyarakat. Peran Notaris pula yang wajib memahami penggunaan teknologi informasi dalam kepengurusan berbagai produk hukum yang akan dihasilkan. Berbagai fakta yang timbul apabila kewenangan kenotariatan masih dilaksanakan secara konvensional, maka pelayanan akan membutuhkan waktu yang cukup lama, berbelit-belit serta sumber daya manusianya tidak menyeimbangakan dengan pekerjaan dan potensi yang ada. Dokumen fisik seperti sertifikat akan rentan untuk rusak, hilang dan mudah dipalsukan. Kewenangan kenotariatan yang dilakukan secara elektronik yang memanfaatkan teknologi informasi dilakukan

${ }^{14}$ R.A. Emma Nurita, Cyber Notary; Pemahaman Awal dalam Konsep Pemikiran, (Bandung: Refika Aditama, 2012), hlm. 17.

15 Edmon Makarim, "Modernisasi Hukum Notaris Masa Depan: Kajian Hukum Terhadap Kemungkinan Cyber Notary di Indonesia", Jurnal Hukum dan Pembangunan Tahun ke-41 No. 3, Juli-September 2011, hlm 493. 
berdasarkan asas kehati-hatian, kepastian hukum, kemanfaatan hukum, itikad baik, serta kebebasan memilih teknologi. ${ }^{16}$

Aturan hukum terkait jabatan notaris yang digunakan Indonesia hingga saat ini merupakan produk hukum yang tidak didasarkan atas hukum nasional modern seluruhnya. Hal ini dipertegas dalam Penjelasan Atas UUJN Bagian I Umum yang menyatakan bahwa sebagian besar peraturan yang diatur dalam UUJN masih didasarkan pada peraturan perundangundangan zaman peninggalan kolonial Hindia Belanda ${ }^{17}$, yang mana pada zaman kolonial belum mengenal adanya transformasi digital dan perkembangan teknologi yang membuat masyarakat melek terhadap teknologi. Kesiapan sarana pendukung tidak perlu diragukan lagi kaitannya dengan teknologi informasi agar diterapkan dalam layanan notaris. Mengenai legalitas suatu akta elektronik tetap dapat memiliki kekuatan hukumnya bahkan di hadapan pengadilan, seperti halnya digital signature, digitally ensured document, dan video conference dalam pembuatan akta antara notaris dan penghadap.

Digital signature diibaratkan sebagai suatu tanda tangan atau dokumen yang telah dikunci dan isinya tidak dapat dimanipulasi. Dalam hal penandatanganan elektronik, para pihak yang terlibat menggunakan kunci yang sama dalam melakukan enkripsi dan dekripsi terhadap suatu dokumen, maka dari itu pihak ketiga atau yang lainnya yang tidak terlibat dalam dokumen, tidak akan dapat mengakses dan memanipulasi dokumen atau tanda tangan tersebut. Penjelasan Pasal 15 ayat (3) UUJN berbunyi "yang dimaksud "kewenangan lain yang diatur dalam peraturan perundangundangan", antara lain kewenangan mensetifikasi transaksi yang dilakukan secara elektronik (cyber notary), membuat akta ikrar wakaf, dan hipotek pesawat terbang". Substansi dalam landasan hukum tersebut cukup mendelegasikan serta menyetujui pelaksanaan kewenangan notaris secara elektronik. Indonesia juga telah memiliki digital signature yang dapat dibuktikan dengan digital certificate terpercaya, yakni layanan PrivyID.

Pasal 1 angka 7 UUJN menyatakan tegas bahwa akta notaris dibuat oleh atau di hadapan Notaris. Substansi dalam pasal ini dapat dikonklusikan bahwa dalam pembuatan akta, wajib dibuat dihadapan notaris dan para pihak secara tatap muka langsung. Hal ini menyebabkan timbulnya polemik dalam masyarakat dalam pengimplementasian cyber notary di Indonesia. Edmon Makarim pada pertemuan rapat pleno Ikatan Notaris Indonesia (INI)

16 Qisthi Fauziyyah Sugianto, "Peluang dan Tantangan Calon Notaris Dalam Menghadapi Perkembangan Disrupsi Era Digital”, Jurnal Notarius, Vol. 12 No. 2, 2019, hlm. 658 .

${ }^{17}$ Bagian I Umum Penjelasan Atas Undang-Undang Republik Indonesia Nomor 30 Tahun 2004 Tentang Jabatan Notaris. 
menyatakan bahwa kehadiran atau penghadapan antara notaris dan penghadap yang dilakukan secara elektronik atau melalui video conference sama halnya dengan kehadiran secara fisik yang selama ini dipersepsikan, sebab pertemuan melalui video conference juga dilakukan secara live atau bertatapan langsung dengan pihak-pihak terkait yang dilibatkan dalam pembuatan akta otentik, baik pembuatan akta partij, maupun akta relaas. ${ }^{18}$

Hal ini senada dengan pendapat Riki Arif Gunawan selaku Deputi Teknologi Kemanan Informasi Menkominfo yang menyatakan bahwa sistem teknologi telah memungkinkan para notaris untuk terjun ke dunia digital dan tidak perlu adanya kekhawatiran lagi terkait pengimplementasian cyber notary di Indonesia. ${ }^{19}$ Serupa namun tak sama, Alwesius selaku Ketua Bidang Program Studi INI buka suara dan menegaskan bahwa pernyataan 'kehadiran fisik' dalam undang-undang tidak dapat konstan dimaknai secara konservatif yang mana kehadiran fisik harus dilakukan dalam satu lokasi yang sama, tetapi pihak terkait harus melek terhadap perkembangan dan mengartikannya sebagai kehadiran melalui video conference..$^{20}$

Berbagai keuntungan dan manfaat yang dapat diperoleh dengan diterapkannya cyber notary yaitu tentunya dalam pelaksanaan tugas Notaris dapat lebih cepat terselesaikan dan meghemat waktu, pelaksanaan transaksi seperti membuat akta/perjanjian hanya perlu dokumen elektronik tetapi para pihak dapat menyelesaikan transaksi bisnisnya, meminimalisir pengeluaran biaya sebab tidak terkendala transportasi dan biaya dapat diperhitungkan, serta hal penting lainnya ialah pelayanan publik dapat diberikan dengan lebih efektif dan efisien dibandingkan dengan layanan secara konvensional.

Akta otentik yang dibuat secara konvensional lebih membutuhkan banyak waktu dan biaya dibandingkan dengan pembuatan akta secara elektronik. Pada umumnya, pembuatan akta-akta oleh Notaris memiliki rincian harga yang tidak mutlak dan berbeda-beda, seperti Pembuatan Akta Perjanjian sebesar Rp2.000.000, Pembuatan Akta dan Pendirian PT sebesar Rp4.000.000, Pembuatan Akta Usaha Dagang sebesar Rp6.500.000, Pendaftaran Merek Dagang sebesar Rp4.500.000, dan lain-lain. ${ }^{21}$ Hal ini tentunya terbatas pada biaya pembuatan akta yang diperlukan saja, namun belum termasuk biaya lainnya seperti transportasi ke berbagai tempat yang harus dikunjungi beberapa kali guna memperoleh pengesahan akta yang

18 PrivyID, 2018, "Kesiapan Notaris Indonesia dalam Menyongsong Cyber Notary", https://blog.privy.id/kesiapan-notaris-menyongsong-cyber-notary/, diakses pada 24 November 2020.

${ }^{19}$ Ibid.

${ }^{20}$ Ibid.

${ }^{21}$ Dunia Notaris, 2021, “Jasa Notaris (Layanan)”, https://dunianotaris.com/shop, diakses pada 12 Januari 2021. 
diperlukan. Namun, dalam hal pembuatan akta secara elektronik, maka akan meminimalisir pengeluaran biaya tersebut. Pertemuan antara Notaris dengan Penghadap digantikan dengan konferensi video elektronik, Notaris dan Penghadap cukup membuka komputer dari lokasi masing-masing tanpa perlu mengeluarkan biaya untuk pergi keluar. Hal ini tentu mempengaruhi efisiensi waktu yang dibutuhkan, dengan adanya transformasi digital, semua akan lebih praktis dan hemat waktu. Proses pembuatan akta oleh Notaris secara konvensional seperti akta jual beli kurang lebih membutuhkan waktu satu bulan hingga selesai pengurusan berkas. Namun, apabila pengurusan berkas dilakukan melalui media elektronik, maka akan lebih efektif dan efisien, berkas yang dibutuhkan dapat diunggah melalui website resmi atau database tujuan yang selanjutnya dapat segera diproses. Cyber Notary tentu membawa banyak keuntungan untuk masyarakat, khususnya dalam pelayanan kenotariatan guna memperoleh pengesahan akta otentik.

Cyber notary erat kaitannya dengan reformasi birokrasi yang merupakan proses perubahan menuju situasi dan kondisi yang dikehendaki guna merespon kondisi birokrasi saat ini serta tuntutan ke arah perbaikan. Website resmi Kementerian Koordinator Bidang Pembangunan Manusia dan Kebudayaan Republik Indonesia atau KEMENKO PMK RI menyebutkan Reformasi Birokrasi ialah cara pemerintah mencapai good governance serta membuat penyempurnaan atau modifikasi mendasar terkait sistem penyelenggaraan pemerintah yang berhubungan dengan aspek ketatalaksanaan, kelembagaan, dan sumber daya manusia aparatur. ${ }^{22}$ Reformasi Birokrasi merupakan suatu gagasan strategis untuk menghadapi Revolusi Industri 4.0 yang dapat diterapkan oleh organisasi pemerintah. Hal ini mencakup tiga aspek fundamental, yaitu inovasi, kolaborasi, dan hal terpenting pemanfaatan teknologi informasi dan komunikasi atau TIK. ${ }^{23}$

Keterkaitan antara cyber notary dengan reformasi birokrasi yaitu cyber notary telah memenuhi ketiga aspek fundamental yang tercakup dalam reformasi birokrasi, yang mana konsep cyber notary sama halnya seperti inovasi baru yang ditawarkan ke arah yang lebih baik guna mempermudah pelayanan publik sehari-hari pada bidang kenotariatan. Cyber notary dilakukan atas dasar kolaborasi antara pihak pemerintah dan Ikatan Notaris Indonesia (INI) dengan maksud melibatkan pemanfaatan teknologi informasi dalam menjalankan tugas dan wewenang notaris seperti

22 Kementerian Koordinator Bidang Pembangunan Manusia dan Kebudayaan Republik Indonesia, 2019, "Reformasi Birokrasi Kemenko PMK", https://www.kemenkopmk.go.id/index.php/RB/profil, diakses pada 5 Januari 2021.

${ }^{23}$ Waston, "Strategi Menang Dalam Revolusi Industri 4.0 (Perspektif Filsafat Thomas Kuhn)", The 10th University Research Colloqium 2019 Sekolah Tinggi Ilmu Kesehatan Muhammadiyah Gombong, hlm. 344. 
melakukan digitalisasi, otentikasi, dan legalisasi berbagai dokumen. Konsep cyber notary bertujuan untuk mencapai layanan pemerintah yang baik dengan maksud melakukan pembaharuan serta perubahan mendasar yang menyangkut aspek ketatalaksanaan bidang kenotariatan.

Karakteristik jabatan notaris berdasarkan UUJN salah satunya yaitu diangkat serta diberhentikan oleh pihak pemerintah atau menteri yang membidangi, yang dalam hal ini notaris dibawahi dan diawasi oleh Kementerian Hukum dan Hak Asasi Manusia (KEMENKUMHAM). ${ }^{24}$ Bentuk kerjasama atau kolaborasi antara pihak pemerintah dan notaris dapat dilihat realitanya pada pembuatan akta pendirian Perseroan Terbatas (PT) oleh Notaris yang menggunakan sistem Administrasi Hukum Umum (AHU) KEMENKUMHAM yang memuat anggaran dasar perseroan sebagai suatu kontrak atau perjanjian pihak perseroan. ${ }^{25}$ Dalam eksekusi pendirian PT oleh Notaris yang menggunakan sistem AHU KEMENKUMHAM wajib berdasar pada aturan Menteri Hukum dan HAM yang berlaku. Dalam hal ini, peran notaris ialah sebagai narasumber atau pihak yang diberi kuasa oleh penghadap (perseroan) dan bertanggung jawab penuh atas pembuatan akta pendirian PT yang menggunakan sistem AHU. ${ }^{26}$ Selain PT, pembuatan akta dengan sistem AHU oleh Notaris, dapat pula dilakukan dalam pembuatan berbagai akta Persekutuan Komanditer (CV), seperti pesan nama $\mathrm{CV}$, pendaftaran $\mathrm{CV}$ baru, perubahan $\mathrm{CV}$, dan pembubaran $\mathrm{CV}$, serta dapat pula dilakukan dalam pembuatan akta wasiat, baik wasiat dalam negeri, maupun wasiat luar negeri. ${ }^{27}$

Dalam hal aspek reformasi birokrasi inilah yang menyangkut kolaborasi atau kerjasama pemerintah (KEMEMKUMHAM) dengan Notaris serta mengedepankan keterlibatan teknologi informasi dalam pelaksanaannya. Realisasi good governance di Indonesia tidak luput dari keberhasilan kinerja birokrasi, sebab kedua hal tersebut memiliki hubungan erat yang positif dan saling mempengaruhi. Birokrasi dan pelayanan publik yang semakin baik, semakin mempengaruhi pembangunan yang baik pula. Sinergi antara pemerintah dan notaris yang kuat dan menghasilkan suatu hal yang lebih efektif, maka mendapat dukungan pula dari masyarakat luas. ${ }^{28}$

${ }^{24}$ Pasal 1 angka 14 Undang-Undang Nomor 2 Tahun 2014 tentang Perubahan Atas Undang-Undang Nomor 30 Tahun 2004 tentang Jabatan Notaris.

25 Adam Azis Rachma Setyawan, "Implementasi Pendirian Perseroan Terbatas Oleh Notaris Menurut Peraturan Menteri Hukum Dan Hak Asasi Manusia Nomor 1 Tahun 2016", Jurnal Privat Law, Vol. V No. 1, Januari-Juni 2017, hlm. 44.

${ }^{26}$ Ibid., hlm. 46.

${ }^{27}$ Direktorat Jenderal Administrasi Hukum Umum, 2020, "Panduan Penggunaan AHU Online”, https://panduan.ahu.go.id/doku.php, diakses pada 6 Januari 2020.

${ }^{28}$ R. Siti Zuhro, "Good Governance dan Reformasi Birokrasi di Indonesia", Jurnal Penelitian Politik Lembaga Ilmu Pengetahuan Indonesia (LIPI), Vol. 7 No. 1, 2010, hlm 2. 
Cyber notary di Indonesia perlu untuk diimplementasikan, sebab hal tersebut merujuk pada adanya efisiensi, efektivitas, dan responsivitas, serta membantu penyelenggaraan pemerintah yang mencapai good governance.

\section{Eksistensi dan Peraturan Perundang-Undangan Cyber Notary di Negara Civil Law (Belgia dan Perancis)}

Civil law merupakan sistem hukum yang memiliki kekuatan mengikat, sebab direalisasikan dalam bentuk peraturan perundang-undangan yang disusun secara sistematis dalam sebuah kodifikasi. Negara-negara di dunia yang menganut sistem civil law diantaranya ialah Indonesia, Belgia, dan Perancis. Dalam hal pengimplementasian cyber notary, maka penelitian ini melibatkan studi komparasi dengan Negara Negara Belgia dan Perancis yang telah melakukan modifikasi hukumnya untuk mengakomodir $e$ authentication atau yang kerap disebut otentikasi dengan sistem elektronik. $^{29}$ Kedua negara tersebut telah mengubah pasal dalam KUHPerdatanya, khususnya terkait pasal tentang akta otentik yang memberikan peluang diimplementasikannya tanda tangan secara elektronik. Eksistensi pada pasal tersebut secara tidak langsung menekankan bahwa apapun teknologinya, sepanjang dapat memenuhi beberapa persyaratan utama, yakni identification, content integrity, dan content approval, maka dapat diterima di muka pengadilan sebagai alat bukti. ${ }^{30}$

Pasal 1322 KUHPerdata Negara Belgia menyatakan "data in electronic form which can be attributed to a determined person and which maintain the integrity of the content of the instrument comply with the legal requirement of a signature", ${ }^{31}$ yang artinya bahwa apapun data yang berbentuk elektronik apabila kaitannya dengan pihak yang telah ditentukan akan menjaga keutuhan isi instrumen tersebut, dikatakan memenuhi persyaratan hukum sebuah tanda tangan yang sah. Begitu pula dalam Belgian Notary Act 16 March 1803 atau yang selanjutnya disebut UUJN Negara Belgia, telah melakukan pertimbangan amandemennya terkait keputusan guna memperbaiki kondisi pembuatan undang-undang cyber notary di bawah kontrol Dewan Nasional Notaris Negara Belgia. ${ }^{32}$ Kaitannya dalam hal tersebut, kemudian timbul peraturan perundangundangan Belgia Law Potpourri V dated 6 July 2017 atau Undang-Undang Potpourri V tanggal 6 Juli 2017 yang membahas terkait cyber notary, terkhusus menegaskan secara spesifik bahwa pelaksanaan akta notaris

${ }^{29}$ Edmon Makarim, Op. Cit., hlm. 497.

${ }^{30}$ Ibid.

31 Edmon Makarim, "Modul Cyber Notary/E-Notary", Research's Team of Technology Law Research Institute Faculty of Law University of Indonesia (LKHT-FHUI), hlm. 27.

${ }^{32}$ Ibid. 
IMPLEMENTASI CYBER NOTARY DI INDONESIA DITINJAU DALAM UPAYA REFORMASI BIROKRASI ERA 4.o (STUDI KOMPARASI DENGAN NEGARA CIVIL LAW) (Fadhila Rizqi, Siti Nurul Intan Sari D.)

sangat memungkinkan dibuat dalam jarak jauh atau melalui video conference. ${ }^{33}$

Serupa namun tak sama, saat ini lebih dari $70 \%$ tindakan yang diterima oleh Notaris di Negara Perancis dilakukan dalam bentuk tanpa kertas. Tindakan otentik pertama yang ditandatangani di media elektronik dilakukan pada tahun 2008. Notaris melibatkan konferensi video pada jaringan komputer guna memfasilitasi pembuatan akta jarak jauh dengan penghadap. ${ }^{34}$ Pasal 1317 KUHPerdata Perancis menyatakan "Instrumen otentik merupakan instrumen yang diterima pejabat publik yang diberi wewenang untuk menyusun instrumen tersebut di tempat instrumen itu ditulis dan dengan formalitas yang dipersyaratkan. Hal ini dapat dibuat di media elektronik yang dibuat dan disimpan dalam kondisi yang ditetapkan.",35

Pada dasarnya, Negara Perancis beranggapan bahwa akta notaris dapat dibuat pada media elektronik dengan ketentuan adanya pelestarian akta dan syarat-syarat memperoleh tanda tangan elektronik wajib terpenuhi. Dalam kondisi ini, tindakan tersebut dapat mempertahankan semua elemen atau kualitasnya, seperti tanggal hukum, kekuatan pembuktian, dan penegakan. ${ }^{36} \mathrm{Hal}$ ini telah diperkuat pada Pasal 1316 KUHPerdata Perancis yang menyatakan bahwa "Sebuah dokumen dalam bentuk elektronik dapat diterima sebagai bukti dengan cara yang sama seperti dokumen berbasis kertas, asalkan orang yang memberikannya dapat diidentifikasi dengan semestinya dan dibuat serta disimpan dalam kondisi yang diperhitungkan untuk mengamankan integritasnya."

Peraturan perundang-undangan Negara Belgia dan Perancis telah mengatur jelas kaitannya dengan legalitas penerapan akta otentik berbasis elektronik, bahkan dalam kehidupan nyata, notaris di kedua negara tersebut telah menerapkan pembuatan akta otentik tanpa kertas dan melibatkan konferensi video dengan penghadapnya. Melihat adanya payung hukum yang jelas terkait cyber notary di Negara Belgia dan Perancis, maka pemberlakuan cyber notary dan regulasinya di Negara Indonesia harus berkaca pada kedua Negara tersebut. Untuk memperoleh landasan hukum yang kuat terkait cyber notary, Indonesia harus mengubah beberapa

33 Loyens Loeff, 2019, "Belgian Notaries and Digitalisation: A (New) Love Affair”, https://www.loyensloeff.com/ch/en/news/belgian-notaries-and-digitalisation-anew-love-affair-n15833/, diakses pada 4 Desember 2020.

34 Notaires de France, 2017, "Electronic Authentic Act or AAE", https://www.notaires.fr/en/notaire/role-notaire-and-his-principal-activities/notarizeddocument-authentic-deed, diakses pada 13 Desember 2020

${ }^{35}$ Edmon Makarim, "Modul Cyber Notary/E-Notary", Loc. Cit

${ }^{36}$ Notaires de France, Loc. Cit.

${ }^{37}$ Edmon Makarim, "Modul Cyber Notary/E-Notary", Loc. Cit. 
regulasinya, diantaranya Undang-Undang Jabatan Notaris, Pasal 1868 Kitab Undang-Undang Hukum Perdata, dan Pasal 5 ayat (4) huruf b UndangUndang Informasi dan Transaksi Elektronik. Dengan adanya perubahan terhadap beberapa regulasi tersebut, diharapkan implementasi cyber notary di Indonesia dapat menjamin dan mengedepankan asas kepastian, kemanfaatan, dan ketertiban hukum, serta memiliki payung hukum yang jelas terkait cyber notary.

\section{KESIMPULAN}

Implementasi cyber notary memiliki berbagai keuntungan, yakni pelaksanaannya akan lebih efektif dan efisien dibandingkan dengan konvensional, baik dari segi tugas, waktu dan biaya. Indonesia juga telah memiliki digital signature atau digital certificate terpercaya, yang mana dokumen akta elektronik tidak perlu diragukan lagi keamanan dan legalitasnya. Keterkaitan cyber notary dengan ketiga aspek fundamental reformasi birokrasi (inovasi, kolaborasi, dan penggunaan TIK) merupakan hal pendukung diimplementasikannya birokrasi cyber notary di Indonesia, sebab dapat membantu penyelenggaraan pemerintah yang mencapai good governance.

Cyber notary di Negara Belgia dan Perancis telah diatur jelas dalam peraturan perundang-undangannya. Dalam praktiknya, notaris di kedua negara tersebut telah membuat akta tanpa kertas dan menggunakan konferensi video dengan penghadapnya. Untuk memperoleh landasan hukum yang kuat terkait cyber notary, Indonesia harus mengubah beberapa regulasi, diantaranya Undang-Undang Jabatan Notaris, Pasal 1868 Kitab Undang-Undang Hukum Perdata, dan Pasal 5 ayat (4) huruf b UndangUndang Informasi dan Transaksi Elektronik.

\section{DAFTAR PUSTAKA}

\section{Buku}

Makarim, Edmon, 2013, Notaris dan Transaksi Elektronik; Kajian Hukum tentag Cyber Notary atau Electronic Notary, Jakarta: PT Raja Grafindo Perkasa.

Nations, United (Department of Economic and Social Affairs), 2020, EGovernment Survey 2020, New York: United Nations.

Nurita, R.A. Emma, 2012, Cyber Notary; Pemahaman Awal dalam Konsep Pemikiran, Bandung: Refika Aditama.

Tobing, Lumbuan, 1983, Peraturan Jabatan Notaris, Jakarta: Erlangga. 
IMPLEMENTASI CYBER NOTARY DI INDONESIA DITINJAU DALAM UPAYA REFORMASI BIROKRASI ERA 4.0 (STUDI KOMPARASI DENGAN NEGARA CIVIL LAW) (Fadhila Rizqi, Siti Nurul Intan Sari D.)

\section{Jurnal}

Makarim, Edmon, 2011, "Modernisasi Hukum Notaris Masa Depan: Kajian Hukum Terhadap Kemungkinan Cyber Notary di Indonesia", Jurnal Hukum dan Pembangunan Tahun ke-41 Nomor 3, Juli-September, hlm 493.

Pratama, Rizky Hersya, "Pelayanan Publik Berbasis Teknologi Informasi dan Komunikasi (TIK), Elektronik Rukun Tetangga/Rukun Warga (e-RT/RW) (Studi e-Government di Kelurahan Ketintang Kecamatan Gayungan Pemerintah Kota Surabaya)", Jurnal Administrasi Publik (JAP), Volume 3, Nomor 12 , hlm. 2129.

Prihanto, Igif G., 2013, "Studi Komparasi Pengembangan e-Government Negara-Negara Anggota Perserikatan Bangsa Bangsa untuk Mendukung Pengembangan e-Government di Indonesia", Jurnal IPTEK-KOM, Volume 15, Nomor 2, Desember, hlm. 157.

Setiadewi, Kadek, 2020, "Legalitas Akta Notaris Berbasis Cyber Notary Sebagai Akta Otentik", Jurnal Komunikasi Hukum (JKH) Universitas Pendidikan Ganesha, Volume 6, Nomor 1, Februari, hlm. 127.

Setiawan, Irfan, 2019, "Pengembangan Teknologi Informasi dan Komunikasi Dalam Menghadapi Era Revolusi Industri 4.0 Di Kota Pontianak", Jurnal Teknologi dan Komunikasi Pemerintahan, Volume 1, Nomor 1, Oktober, hlm. 3.

Setyawan, Adam Azis Rachma, 2017, "Implementasi Pendirian Perseroan Terbatas Oleh Notaris Menurut Peraturan Menteri Hukum Dan Hak Asasi Manusia Nomor 1 Tahun 2016", Jurnal Privat Law, Vol. V No. 1, hlm. 44.

Sinaga, Herianto, 2015, “Tanggung Jawab Werda Notaris Terhadap Akta yang Dibuatnya", Jurnal Premise Law, Volume 6, hlm. 1.

Sugianto, Qisthi Fauziyyah, 2019, "Peluang dan Tantangan Calon Notaris Dalam Menghadapi Perkembangan Disrupsi Era Digital", Jurnal Notarius, Volume 12, Nomor 2, hlm. 658.

Waston, 2019, "Strategi Menang Dalam Revolusi Industri 4.0 (Perspektif Filsafat Thomas Kuhn)", The 10th University Research Colloqium 2019 Sekolah Tinggi Ilmu Kesehatan Muhammadiyah Gombong, hlm. 344.

Yusriadi, Misnawati, 2017 "Reformasi Birokrasi Dalam Pelayanan Publik (Studi Pelayanan Terpadu Satu Pintu)", Jurnal Ilmiah Ilmu Administrasi Publik, Volume 7, Nomor 2, Juli - Desember, hlm. 100 . 
Zuhro, R. Siti, 2010, "Good Governance dan Reformasi Birokrasi di Indonesia", Jurnal Penelitian Politik Lembaga Ilmu Pengetahuan Indonesia (LIPI), Vol. 7 No. 1, hlm 2.

\section{Modul \& Tesis}

Makarim, Edmon, "Modul Cyber Notary/E-Notary", Research's Team of Technology Law Research Institute, Faculty of Law University of Indonesia.

Putri, Respati Nadia, 2017, "Konsep Cyber Notary Dalam Perubahan Undang-Undang Jabatan Notaris Sebagai Hasil Program Legislasi Nasional", Tesis Magister, Fakultas Hukum Universitas Padjadjaran Bandung.

\section{Peraturan Perundang-Undangan}

Indonesia, Undang-Undang Nomor 30 Tahun 2004 tentang Jabatan Notaris.

\section{Internet}

France, Notaires de, 2017, "Electronic Authentic Act or AAE", https://www.notaires.fr/en/notaire/role-notaire-and-his-principalactivities/notarized-document-authentic-deed, (diakses pada 13 Desember 2020).

Kementerian Pendayagunaan Aparatur Negara dan Reformasi Birokrasi, 2009, "Reformasi Birokrasi", https://www.menpan.go.id/site/reformasibirokrasi/makna-dan-tujuan, (diakses 26 Oktober 2020).

Loeff, Loyens, 2019, "Belgian Notaries and Digitalisation: A (New) Love Affair", https://www.loyensloeff.com/ch/en/news/belgian-notaries-anddigitalisation-a-new-love-affair-n15833/, (diakses pada 4 Desember 2020).

Notaris, Dunia, 2021, "Jasa Notaris (Layanan)", https://dunianotaris.com/shop, (diakses pada 12 Januari 2021).

PrivyID, 2018, "Kesiapan Notaris Indonesia dalam Menyongsong Cyber Notary", https://blog.privy.id/kesiapan-notaris-menyongsong-cybernotary/, (diakses pada 24 November 2020).

Republik Indonesia, Kementerian Koordinator Bidang Pembangunan Manusia dan Kebudayaan, 2019, "Reformasi Birokrasi Kemenko PMK", https://www.kemenkopmk.go.id/index.php/RB/profil, (diakses pada 5 Januari 2021).

Umum, Direktorat Jenderal Administrasi Hukum, 2020, "Panduan Penggunaan AHU Online", https://panduan.ahu.go.id/doku.php, (diakses pada 6 Januari 2020). 